\title{
Genetically enhanced Olympics are coming
}

\section{Future Olympic Games may allow handicaps and gene therapy for people born without genes linked to athleticism, predict Juan Enriquez and Steve Gullans.}

$\mathrm{O}$ lympians can run faster, leap higher and lift more than 'normal' humans. Of course, such elite athletes earn their titles with an astonishing amount of hard work and support. But many also have some unearned advantages: the right genes.

There is growing evidence that worldclass athletes carry a minimum set of particular 'performance-enhancing' genes. For instance, almost every male Olympic sprinter and power athlete ever tested carries the 577R allele, a variant of the gene ACTN3. About half of Eurasians and $85 \%$ of Africans carry at least one copy ${ }^{1}$ of this 'power gene. The billion or so other people who lack the 577R allele might wish to reconsider their Olympic aspirations.

More and more genes are now being linked to athletic prowess, and future Olympic officials will have to wrestle with the implications. Are the games in fact a showcase for hardworking 'mutants'? And if Olympic rule-makers admit that the genetic landscape is uneven, should they then test every athlete and hold separate competitions for the genetically ungifted?

There are three basic scenarios for future Olympics. First, the competition could continue as a showcase of athletes born with genetic advantages. Another option would be to use handicaps - similar to those that are now used in several non-Olympic sports - to level the playing field for athletes who do not carry beneficial genes. A third option, if safe, would be to allow athletes who did not win the genetic lottery to 'upgrade' through gene therapy - a practice that is now banned as 'gene doping'.

We have been living in the first scenario for centuries. More than 200 gene variants are already associated with athleticism ${ }^{2}$. For example, carriers of the 'I' variant of the gene $A C E$ are more likely than non-carriers to successfully climb an 8,000-metre peak ${ }^{3}$. The I variant is present in $94 \%$ of Sherpas in the Kathmandu Valley of $\mathrm{Nepal}^{4}$, but in only $45-70 \%$ of people of other ethnicities ${ }^{5}$. It is associated with increased endurance. A study of British runners found that it is most common in those who race the longest distances ${ }^{6}$.

Such variants occur frequently in the human population, and athletes probably

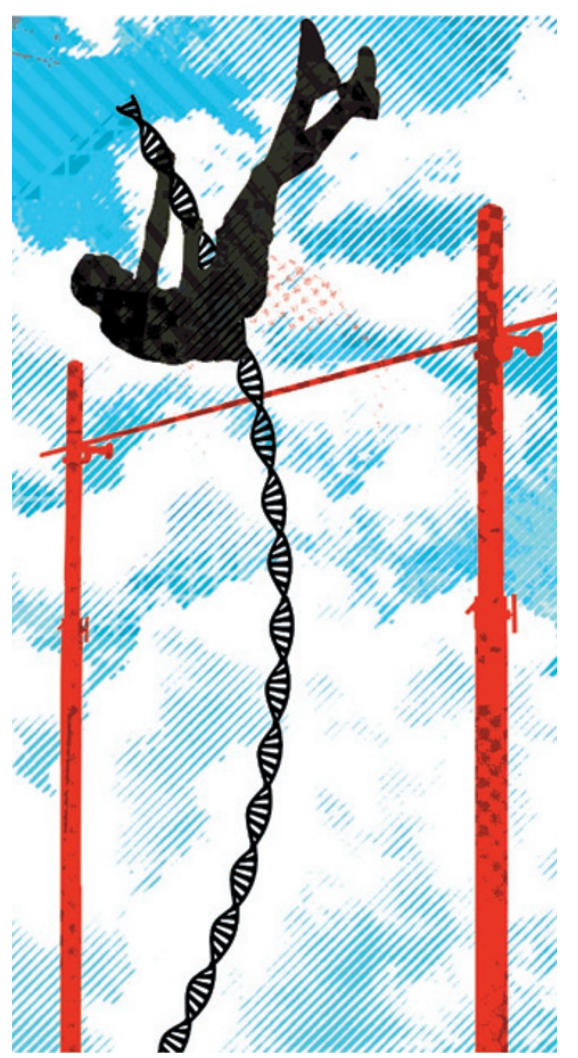

need a subset of them to achieve elite status. As more individual genomes are sequenced, researchers will begin to detect some rare variants that differentiate truly superior champions from mere world-class athletes. Eero Mäntyranta had a mutation in the gene EPOR that caused him to produce extra red blood cells, boosting his oxygen-carrying capacity by $25-50 \%$ (ref. 7 ), which probably helped him to earn seven Olympic crosscountry ski medals.

But how easily could scientists detect whether a variant is natural or introduced? Even 'gender-verification' testing to confirm the sex of female competitors has been problematic, given the natural biological variation among individuals ${ }^{8}$.

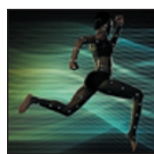

LET THE GAMES BEGIN Science and the Olympics nature.com/olympics 2012
Olympic traditions change glacially, but eventually, what was once unthinkable becomes commonplace. Once upon a time, women were allowed to compete only in Olympic tennis, golf and croquet. Until the 1970s, paid athletes were banned from Olympic competition - now, professional basketball players compete for medals. And 'extreme sports' such as snowboarding and bicycle motocross have now become Olympics-worthy.

As officials struggle with the implications of genetic data and upgrades, we will probably see, initially, a set of draconian rules against gene modification. Will a competitor who was cured of sickle-cell anaemia by gene therapy as a child be excluded? How about someone cured of an EPOR defect through use of Eero Mäntyranta's natural variant?

Just as Oscar Pistorius, the Paralympic champion runner who was once banned from the Olympics because he uses leg prostheses, will now compete in London on the South African relay team, we expect that as genetic modification becomes more common, a gradual acceptance of safe genetic enhancements will follow. After all, we watch the games today to marvel at athletes who are 'faster, higher, stronger' - whether man or woman, amateur or professional, 'disabled' or not.

Juan Enriquez and Steve Gullans are managing directors of Excel Venture Management, Boston, Massachusetts 02199, USA, and the authors of Homo Evolutis: Please Meet the Next Human Species (TED Conferences, 2011).

e-mail:jenriquez@excelvm.com

1. Berman, Y. \& North, K. N. Physiology 25, 250-259 (2010).

2. Ostrander, E. A., Huson, H. J. \& Ostrander, G. K. Annu. Rev. Genomics Hum. Genet. 10, 407-429 (2009).

3. Thompson, J. et al. High Alt. Med. Biol. 8 , 278-285 (2007).

4. Droma, Y. et al. Wilderness Environ. Med. 19, 22-29 (2008)

5. Sonna, L. A. et al. J. Appl. Physiol. 91, 1355-1363 (2001).

6. Myerson, S. et al. J. Appl. Physiol. 87, 1313-1316 (1999).

7. de la Chapelle, A., Träskelin, A. L. \& Juvonen, E. Proc. Natl Acad. Sci. USA 90, 4495-4499 (1993).

8. Karkazis, K., Jordan-Young, R., Davis, G. \& Camporesi, S. Am. J. Bioeth. 12, 3-16 (2012). 